\title{
Peningkatan Desain dan Ketrampilan Batik Celup Ikat untuk Meningkatkan Minat Wira Usaha Masyarakat
}

\section{Mahendra Wardhana}

Dosen dan Peneliti Jurusan Desain Interior ITS, Surabaya, Indonesia

mahendra.interior@gmail.com

\begin{abstract}
ABSTRAK
Batik merupakan warisan budaya di Negara Indonesia yang sangat memiliki nilai jual yang tinggi dan prospek ekonomi yang tinggi pula. Kekayaan batik bisa dilihat dari desain motifnya yang beragam dan kaya akan nilai-nilai kreatifitas. Berbagai corak desain motif batik telah dikembangkan dan menjadi kekayaan ciri daerah di berbagai belahan daerah di Indonesia.

Peluang untuk menaikkan minat wira usaha khususnya di bidang batik adalah dicapai dengan tiga tahapan yakni mengenalkan, mencoba dan mengetahui peluangnya. Dari tiga tahapan tersebut, tahapan mengenalkan dan mencoba membuat akan dibahas pada kesempatan ini.

Salah satu kemudahan dalam mengenalkan batik adalah dengan mencoba langsung berkreasi di kain batik. Kemudahan dan keunikan hasil batik akan langsung didapat setelah proses membatik selesai. Untuk menunjang kemudahan tersebut, maka dilaksanakanlah batik celup ikat untuk mendukung tujuan tersebut. Hasil yang dicapai adalah keunikan hasil batik ternyata dapat meningkatkan minat berwira usaha membatik tersebut.
\end{abstract}

Kata kunci: Batik, Indonesia, unik, celup ikat

\section{ABSTRACT}

Batikis Indonesia's cultural heritage which has a very high value and high economic outlook as well. Batik uniqueness can be seen from the design of batik motives are varied and rich increativity values. Various shades of batik design has been develop and the wealth of local characteristics in different parts of regions in Indonesia.

Opportunity to raise the motivation and interest of entrepreneurship, especially in the field of batik are achieved by introducing three phases namely, to try and determine his chances. Those three stages are the stages of introducing and try to make will be discussed on this occasion.

One of the chances of introducing batik is to try to direct the creative in batik cloth. The chances and uniqueness results of batik will be immediately obtained after the batik processis completed. To support such ease, then the tie-dyed batik done to support these objectives. While the result is the unique result of batik was found to increase interest entrepreneur the batik business.

Keywords: Batik, Indonesia, Unique, tie-dyed

\section{PENDAHULUAN}

Batik telah menjadi kekayaan budaya sekaligus menjadi primadona masyarakat dalam meningkatkan penghasilannya. Batik telah dikenal luas oleh semua kalangan di Indonesia. Hal ini adalah dikarenakan batik merupakan warisan leluhur sejak lama di Indonesia. Ke depannya, kesempatan mengolahan batik pada berbagai elemen menjadi salah satu peluang untuk meningkatkan nilai penjualan batik tersebut. Dengan meningkatkan motif dan termasuk metode saat ini menjadi salah satu peluang lain yang cukup menjanjikan [3][4][5]. Salah satu metode atau teknik membatik yang cukup sederhana namun memiliki nilai keunikan yang tinggi adalah dengan teknik celup dan ikat (tie-dyed). Teknik ini akan menghasilkan motif 
pewarnaan yang unik pada kain batik. Jadi keunikannya tidak pada gambaran canting pada kain batik, namun pola atau cara menahan warna pada kain batik.

Permasalahan yang dibahas pada makalah ini adalah bagaimana mengenalkan asas pengetahuan membatik pada masyarakat yang masih belum menjadi perajin batik, sehingga menjadi tertarik pada bidang usaha batik.

Dalam upaya ini kasus studi yang diangkat adalah pada ibu-ibu di lingkungan RT 04 RW 03 Kelurahan Semolowaru Selatan. Dalam kesempatan tersebut dilaksanakan dengan mengarahkan teknik workshop bersama. Kesan batik yang ditimbulkan adalah berkesan klasik[1]. Selain itu upaya penggalian motif batik telah dilakukan oleh berbagai kalangan diantaranya oleh Indraprasti (2013).

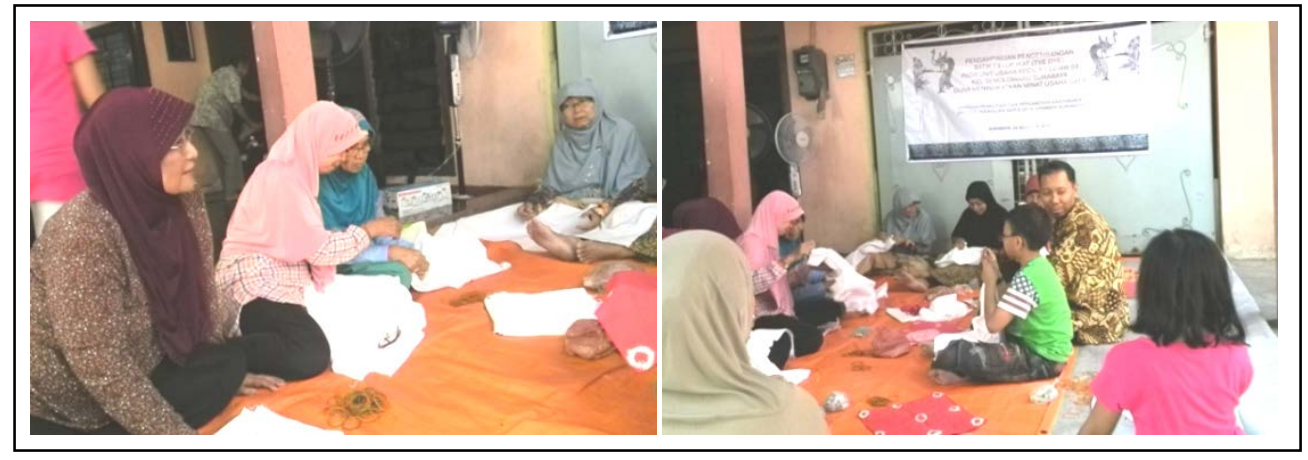

Gambar 1. Proses Membatik yang Telah Dilakukan.

Sumber : Dokumentasi Penulis (2015)

\section{METODOLOGI}

Metode yang digunakan untuk mengoptimalkan dalam mencapai tujuan di atas adalah dengan melaksanakan proses pendampingan selama pelatihan. Rencana kegiatan dalam upaya tersebut adalah dilaksanakan secara bertahap dan urut dalam satu kegiatan pelatihan. Tahapan kegiatan tersebut adalah:

1. Pengenalan batik

2. Praktek membatik

3. Pendalaman batik dengan teknik celup ikat

4. Pengembangan keahlian membatik pada barang-barang rumah tangga

Tahapan-tahapan di atas dilaksanakan secara urut dengan dilaksanakan oleh tim pengabdian dengan peserta pelatihan. Kegiatan tersebut memiliki jangka waktu 1 hari kegiatan. Proses tersebut memerlukan waktu hingga sekurang-kurangnya 5 jam hingga selesainya proses kegiatan tersebut.

Guna memperoleh output pelaksanaan yang maksimal, maka dibutuhkan kegiatan yang berkesinambungan. Hal ini dikarenakan :

1. Unit usaha berada di lingkungan sekitar Kampus ITS sehingga dapat mudah dalam kunjungannya. Kedekatan jarak antara mitra dengan tim pengabdian dari Jurusan Desain Interior ITS akan menghemat waktu, biaya, tenaga dan akomodasi pada keberlanjutan pengabdian ini.

2. Batik yang dihasilkan dapat dikembangkan kepada beraneka barang rumah tangga dengan berbagai kratifitasnya. Kretaifitas ini akan dapat berkesinambungan dilaksanakan mengingat tim pengabdian dari Jurusan Desain Interior ITS menjadi motor penggali kreatifitas desain batik bagi unit usaha mitra. 
3. Penggalian motif dan kekayaan batik dapat dilaksanakan dengan mudah di masa mendatang dikarenakan sudah terdapat pengabdian ini yang mendahuluinya.

\section{PEMBAHASAN}

Pelaksanaan kegiatan pendampingan ini dilaksanakan dengan tiga tahapan yakni:

1. Pengenalan Batik

Merupakan kegiatan-kegiatan pengenalan batik secara umum dan teknik membatik. Keunikan batik akan terlihat dengan menampilkan contoh-contoh batik yang menarik.

2. Praktek Membatik

Kegiatan ini adalah merupakan kegiatan praktek membatik dengan pola kerja kelompok secara bersama-sama. Peserta akan dapat menanyakan sesuatu selama pelatihan apabila dirasakan ada yang perlu ditanyakan.

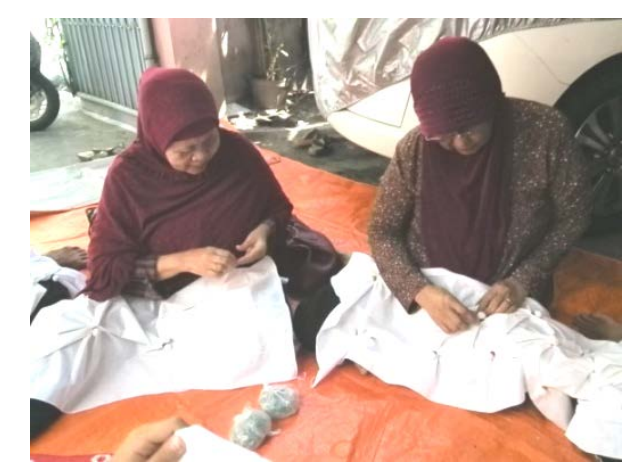

Gambar 2. Proses Memberikan Pola dalam Batik dengan Teknik Batik Celup Ikat Sumber : Dokumentasi Penulis (2015)

3. Pendalaman Batik dengan Teknik Celup Ikat.

Pendalaman teknik ikat celup dilaksanakan dengan secara bersama-sama melaksanakan pembatikan secara bertahap. Tahapan-tahapan akan dilaksanakan secara bersamaan dengan instruktur yang ada.

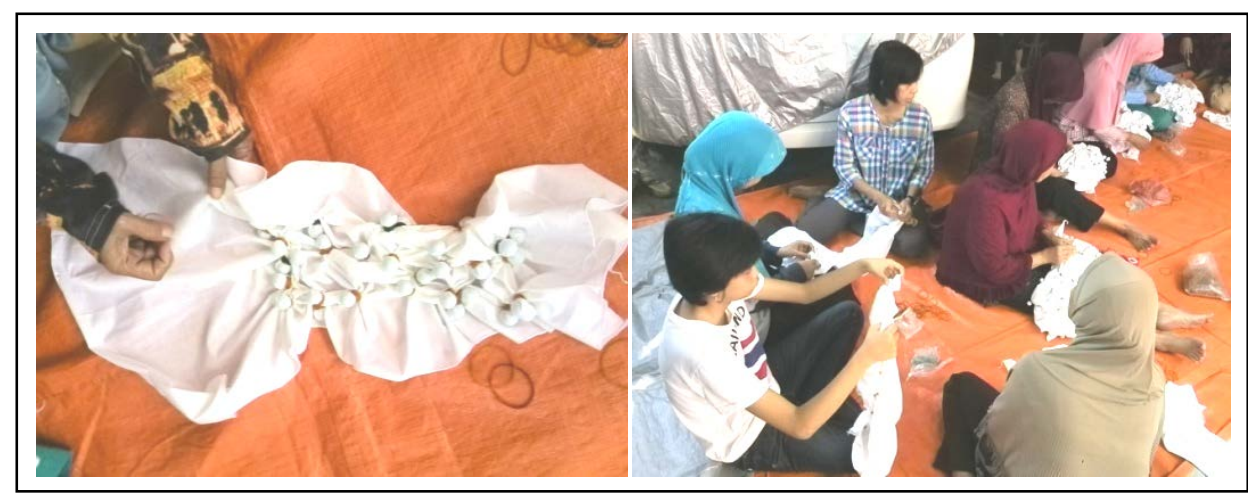

Gambar 3. Proses Membatik Celup Ikat

Sumber : Dokumentasi Penulis (2015)

4. Pengembangan Keahlian Membatik pada Barang-Barang Rumah Tangga.

Pengambangan ini dilaksanakan dengan mengenalkan contoh-contoh aplikasi batik pada barang-barang rumah tangga. Pengenalan tersebut menjadi dasar pengenalan usaha wiraswasta mengembangkan batik. 


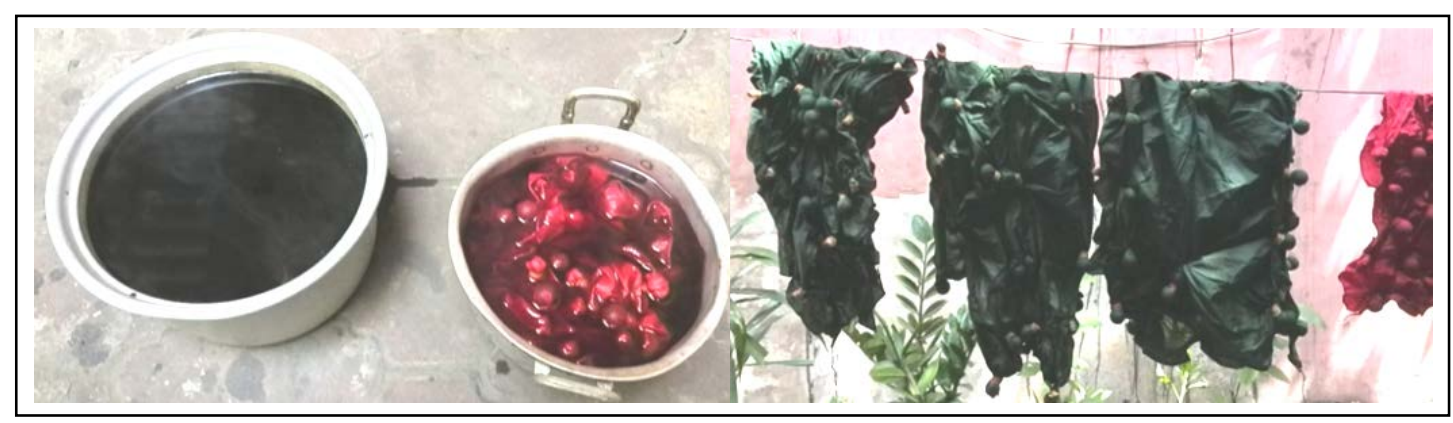

Gambar 4. Proses PembuatanBatik Celup Ikat. Sumber : Dokumentasi Penulis (2015)

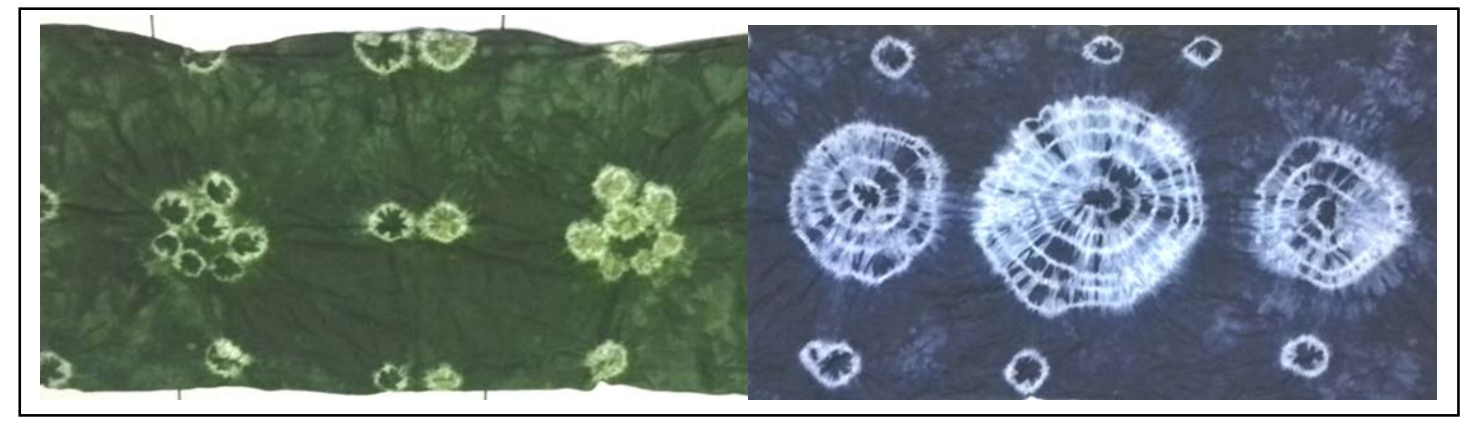

Gambar 5. Aplikasi Batik Celup Ikat yang Sudah Selesai Dibuat Sumber : Dokumentasi Penulis (2015)

\section{KESIMPULAN}

Berdasarkan hasil pelatihan yang dilaksanakan, maka penguasaan batik dengan teknik celup ikat tersebut memiliki berbagai keunikan yang dapat digali dengan lebih baik. Salah satu keunggulan teknik batik ini adalah karena pola tali yang menahan warna masuk kepada kain yang dibatik. Selain itu, keunggulan batik dengan teknik ini akan menjadikan ciri yang berbeda dengan batik pada umumnya.

Gabungan teknik desain membatik dengan teknik celup ikat ini selanjutnya akan menjadi lebih baik pola batik yang dihasilkannya.

\section{PUSTAKA}

[1] Dharsono. (2007). Budaya Nusantara. Bandung : Penerbit Rekayasa Sains.

[2] Indraprasti, Anggri. (2013). Pengembangan Motif Batik Berkarakter Arsitektur Kota untuk Meningkatkan Nilai Jual Batik Lokal. Surabaya : Penelitian Strategis Nasional 2013.

[3] Munandar, Agus Aris. (2008). Ibukota Majapahit, Masa Kejayaan dan Pencapaian. Depok : Komunitas Bambu.

[4] Kawuryan, Megandaru W. (2006). Tata Pemerintahan Negara Kertagama Kraton Majapahit. Yogyakarta : Panji Pustaka.

[5] Purwadi. (2006). Babad Tanah Jawa. Yogyakarta : Panji Pustaka. 